\title{
Degeneración del 70: heterodoxa antología andaluza frente a las poéticas hegemónicas ${ }^{1}$
}

\author{
Blas Sánchez Dueñas \\ Universidad de Córdoba
}

Título: Degeneración del 70: heterodoxa antología andaluza frente a las poéticas hegemónicas.

Resumen: El paisanaje poético aglutinó en la década de los setenta una heterogénea polaridad de corrientes en un caleidoscópico contexto en transición. Aunque desde diferentes medios y con variados paradigmas se ha tratado de iluminar aquella producción, aún quedan esferas en sombra que deben ser rehabilitadas. Este trabajo estudia el cuerpo textual de la antología Degeneración del 70, promovida por el colectivo cordobés Antorcha de paja. Ejemplo de ideario contracultural y propuesta ética y estética disidente respecto a las corrientes de entonces, se recuperan aquí las voces de los poetas heterodoxos agrupados en dicho volumen, con vistas a rescatarlo dentro de los amplios horizontes de la lírica de la Transición, muchos de ellos orillados por el canon de nuestros días.

Palabras clave: Poesía, Transición, Antorcha de Paja, Degeneración del 70, Disidencia.

Fecha de recepción: 19/03/2021.

Fecha de aceptación: 07/04/2021.
Title: Degeneración del 70: an Andalusian Heterodox Anthology versus Hegemonic Poetics.

Abstract: The poetic landscape of the 70 s brought together a heterogeneous polarity of currents in a kaleidoscopic context of transition. Although different media, with a range of paradigms, have sought to shed light on that production, there are still murky areas in need of elucidation. This work studies the textual body of the anthology Degeneración del 70, promoted by the Cordovan group Antorcha de paja. An example of countercultural ideology and a transgressive ethical and aesthetic proposal with respect to the trends of the time, the voices of the heterodox poets grouped in this volume are recovered here with a view to rescuing them within the broad horizons of Transition-era poetry, many of them overlooked by the canon today.

Key words: Poetry, Transition, Antorcha de Paja, Degeneración del 70, Dissidence.

Date of Receipt: 19/03/2021.

Date of Approval: 07/04/2021.

1 Proyecto de Investigación del Plan Estatal "Poéticas de la Transición (1973-1982)", financiado por: FEDER/Ministerio de Ciencia, Innovación y UniversidadesAgencia Estatal de Investigación/ FFI2017-84759-P. 


\section{INTRODUCCIÓN}

Desde diferentes medios, evidenciados en los estudios de Lanz ${ }^{2}$, Labrador $^{3}$, Iravedra ${ }^{4}$ y Prieto de Paula ${ }^{5}$, se ha tratado de iluminar las poéticas generadas durante los setenta, producto de una realidad tan incierta y mudable como difícil de fijar en cánones estéticos; lo cual ha suscitado numerosas interpretaciones parciales y no pocos intentos de clarificación, amén de unas lecturas que complican las definiciones de los paradigmas doctrinales de una década que tuvo en la antología Nueve novísimos poetas españoles (1970) Castellet un referente sustancial ${ }^{6}$, y al grupo en él recogido, a pesar de sus singularidades, como "figuras relevantes", según la terminología de Harold Bloom ${ }^{7}$.

Con objeto de ponderar, acreditar y clasificar ciclos estéticos, en las sociedades postmodernas la práctica de las antologías se ha convertido en instrumento esencial de periodización, al erigirse como herramienta indispensable de la constante recuperación y reelaboración de la memoria sincrónica ${ }^{8}$. Las investigaciones sobre algunas de las más significativas de entonces ofrecen dechados significativos a la hora de desentrañar los horizontes desde los que vislumbrar la geografía de dicha cohabitación. Como botón de muestra, en los primeros setenta disfrutaron de interés crítico y mediático los volúmenes Nueve novisimos poetas españoles de Castellet ${ }^{9}$, Nueva poesía española (1970) de Martín Pardo ${ }^{10}$, y Espejo del amor y de la

2 Juan José Lanz, Páginas del 68. Revistas poéticas juveniles 1962-1977, Salamanca, Junta de Castilla y León, 2007; La poesía durante la transición y la generación de la democracia, Madrid, Devenir, 2007.

3 German Labrador Méndez, Culpables por la literatura. Imaginación política y contracultura en la transición española (1968-1986), Madrid, Akal, 2017.

4 Araceli Iravedra, Hacia la democracia. La nueva poesia (1968-2000) [Antología crítica], Madrid, Visor, 2016.

5 Ángel Luis Prieto de Paula, Musa del 68. Claves de una generación poética, Madrid, Hiperión, 1996.

6 José María Castellet, Nueve novisimos poetas españoles, Barcelona, Barral, 1970.

7 Harold Bloom, El canon occidental. La escuela y los libros de todas las épocas, Barcelona, Anagrama, 1995.

8 Miguel Gallego Roca, Antología de la joven poesia granadina, Granada, Caja General de Ahorros, 1999, p. 7.

9 Castellet, op. cit.

10 Enrique Martín Pardo, Nueva poesía española, Madrid, Scorpio, 1970. 
muerte (1971) de Prieto ${ }^{11}$; repertorios que presentaban a los nuevos nombres de un cambio estético y doctrinal que, no obstante, alternaban con otros más vastos y aglutinadores, los cuales procuraban deslindar voces e itinerarios de cauces previos como ejemplifican la Antología de la poesía española contemporánea (1970) de Moreno Báez ${ }^{12}$ y La nueva poesía española (Antología crítica) (1971) de Martínez Ruiz ${ }^{13}$; o aquellos que trazaban caminos más heterodoxos y experimentales, verbigracia el titulado Equipo Claraboya. Teoría y poemas (1971) a cargo del colectivo leonés Claraboya ${ }^{14}$.

Algo similar ocurrió hacia el final de la década. Los florilegios no sólo continuaron creciendo exponencialmente, sino que ahondaron en sus intentos de clarificación de las tendencias e itinerarios de un panorama literario cada vez más complejo. En 1978 veían la luz las dos antologías que terminaron por configurar el canon de la Generación del 50: El grupo poético de los años 50 de García Hortelano ${ }^{15}$ y Una promoción desheredada: la poética del 50 de Hernández ${ }^{16}$, resueltos a recapitular e historizar el esbozo de un grupo más o menos configurado ${ }^{17}$. Un año más tarde, Moral y Pereda publicaron Joven poesía española ${ }^{18}$, que contribuyó a estructurar definitivamente los nuevos rumbos y escisiones de la lírica de los setenta y a apuntalar el cambio estético y generacional. Dicha floresta sería ampliada por Las voces y los ecos (1980) de García Martín ${ }^{19}$. Ambas aspiraban a cumplir la tarea de incitación estética frente a las del comienzo de la década, que respondían a criterios programáticos ${ }^{20}$.

11 Antonio Prieto, Espejo del amor y de la muerte, Madrid, Azur, 1971.

12 Enrique Moreno Báez, Antología de la poesía española contemporánea, Barcelona, Salvat, 1970.

13 Florencio Martínez Ruiz, La nueva poesía española (Antología crítica), Madrid, Biblioteca nueva, 1971.

14 AA.VV. Equipo Claraboya. Teoría y poemas, Barcelona, El Bardo, 1971.

15 Juan García Hortelano, El grupo poético de los años 50, Madrid, Taurus, 1978.

16 Antonio Hernández, Una promoción desheredada: la poética del 50, Bilbao, ZeroZix, 1978.

17 Enrique Balsameda Maestu, "La poesía española de posguerra a través de sus antologías", Cuadernos de Investigación Filológica, XIV (1998), pp. 41-55 (p. 53).

18 Concepción G. Moral y Rosa María Pereda, Joven poesía española. Antología, Madrid, Cátedra, 1979.

19 José Luis García Martín, Las voces y los ecos, Madrid, Júcar, 1980.

20 Prieto de Paula, op. cit., p. 77. 
Dentro de este horizonte de coexistencias, surgieron otros grupos periféricos y disidentes cuyas heterodoxas propuestas - a través de antologías, revistas, iniciativas culturales y actos colectivos - trataron de hacerse un hueco en el panorama lírico. Desde diferentes lugares, se cuestionaron los postulados canónicos y la hegemonía de unas particulares líneas ideológicas y estéticas en detrimento del resto de propuestas que, con divergentes idearios y heterogéneas doctrinas, aspiraban a dejarse oír y ocupar un espacio en ámbito poético de la Transición.

\section{ANTorcha de Paja: vindicación de la heterodoxia literaria}

Uno de los grupos más combativos durante la Transición, en su afán por despejar nuevas propuestas e impulsar redes contestatarias en contra de lo hegemónico, fue Antorcha de Paja. Este colectivo cordobés tuvo como principales vehículos la publicación de una homónima revista rupturista, iconoclasta y heterodoxa respecto a los cauces literarios y hemerográficos del momento —ampliamente analizados en estudios como los de $\mathrm{Ru}$ bio $^{21}$, Ramos Ortega ${ }^{22}$, Lanz $^{23}$ y Guzmán Simón ${ }^{24}$ — y la edición de una antología significativamente titulada Degeneración del 70 (Antología de poetas heterodoxos andaluces).

Antorcha de paja surgió en 1973, fruto del encuentro de varios jóvenes poetas miembros de un grupo precursor denominado Zubia, donde habían coincidido con el fin de estampar un proyecto editorial periódico que no consiguió ahormarse hasta varios años más tarde ${ }^{25}$.

El primer número de la revista salió en 1973, en forma de pliego, en el sentido estricto de la palabra ya que se reducía a una sola hoja de 46 x 46 cms., plegada dos veces. Apenas cinco firmas aparecían entre sus

21 Fanny Rubio, Las revistas poéticas españolas (1939-1975), Madrid, Turner, 1976.

22 Manuel Ramos Ortega, (ed.), Revistas literarias españolas del siglo XX (1919-1975), Madrid, Ollero y Ramos, 2005, III.

23 Lanz, op. cit.

24 Fernando Guzmán Simón, La poesía andaluza de la transición (1966-1982). Revistas $y$ antologias, Sevilla, Universidad de Sevilla, 2008 [tesis doctoral].

25 Manuel Gahete, "Veinticinco años de poesía en Córdoba: el cauce de Zubia", Boletín de la Real Academia de Córdoba, Bellas Letras y Nobles Artes, LXXVII, 137 (1999), pp. 219-236. 
dobleces; cuatro de ellas correspondían al grupo fundador procedente de Zubia: Francisco Gálvez, José Luis Amaro, Rafael Madueño de la Torre y Pedro Luis Zorrilla, a quienes se unió en la empresa el también cordobés Rafael Álvarez Merlo.

La revista apareció de forma ocasional. Gálvez editó este primer número con la intención de que fuera el único ${ }^{26}$, si bien, enseguida, la iniciativa se vio secundada por el resto de sus colegas para fraguar un ambiguo proyecto editorial. En sus entregas iniciales, no había nada en su cuerpo que lo definiera como revista o publicación periódica más o menos ortodoxa. Su carácter subversivo devenía también de su periodicidad irregular, así como de los juegos con la disposición textual que obliga a una lectura activa y dinámica: había que girar el papel para acceder a cada uno de sus textos. Además de la libertad en su estructura y en sus ritmos de estampa, Antorcha de paja jugó con las tipografías, incrementó a trescientos en el número de ejemplares, incorporó nuevas plumas a sus páginas — casi siempre poetas jóvenes vinculados a Andalucía-y brindó contenidos regeneradores ${ }^{27}$.

Como decimos, sus editores se impusieron los principios de la actitud crítica, del recelo y de la voluntad renovadora como bases de un proyecto que aspiraba a convertirse en "testimonio vivo de $\mathrm{NO}$ quererse morir en una poesía hartamente hundida en el pozo del tiempo, hermética y limitada" $\left(\mathrm{n}^{\circ} 1\right)^{28}$. Su primera etapa la coparon las aportaciones de su grupo editor y de vates andaluces, secuela de sus críticas a los dictados poéticos madrileños y barceloneses, y también de su intento de reivindicación de la lírica andaluza. Sin embargo, no se sustrajeron a las modas subyacentes, empezando por la estética veneciana y barroquizante. Por aquellos días, incorporaron a poetas jóvenes como Jaime Siles y Marcos-Ricardo Barnatán, emblemas de una depuración lingüística típica de mediados de los setenta.

El regreso de la revista en la primavera de 1976 marcó el inicio de una nueva singladura, visible, entre otros aspectos, en su formato, que pasó de un pliego doblado y sin cortes a un cuadernillo de doce páginas. De nue-

26 Juan José Lanz, Antorcha de Paja. Revista de poesia (1973-1983), Madrid, Devenir, 2012, p. 11.

27 Pedro Ruiz Pérez, "Antorcha de Paja (Córdoba, 1973-1983): una revista para los 70", en Revistas literarias españolas del siglo XX (1919-1975), III, ed. Manuel Ramos Ortega, Madrid, Ollero y Ramos, 2005, pp. 325-352 (p. 329).

28 Sin autor, Antorcha de paja, 1 (1973). 
vo se amplió su tirada y se acentuó el carácter monográfico de sus núme$\operatorname{ros}^{29}$. Lo más característico fue la consolidación de sus teorías reforzadas a través de los editoriales en las cabeceras. Abogaban allí por el rechazo al sistema establecido, el combate desde la periferia frente al centralismo dominante, los azotes al desprestigio de los premios literarios otorgados a los de siempre, la demanda de atención a nuevas voces y la relevancia de las revistas poéticas como órganos de difusión y renovación a pesar de su abandono y precariedad ${ }^{30}$.

Rotas las compuertas interventoras del Régimen, según se desprende de sus editoriales, analizados por Rosal ${ }^{31}$ y Ruiz Pérez ${ }^{32}$, Antorcha de Paja apadrinó un avance renovador mediante nuevas propuestas — un tanto alejadas de las más sustantivas del momento- al apostar por la redención de una cultura popular auténtica, alejada de folklorismos vacíos, por el poder social de la cultura y por el reclamo de ruptura con el pasado a través de la rebelión. Todo lo cual llevó a la revista a una acentuada "voluntad de renovación a partir de la estética vigente y la afirmación de la poesía como praxis y verdad, ya se vuelva hacia la experiencia íntima o se vuelque a la consideración del mundo exterior, metafísico, social o poético"33.

En líneas generales, de acuerdo con Lanz, sus miembros aspiraron a fracturar los cánones establecidos desde los núcleos centralistas del eje Madrid-Barcelona; lanzar gritos de rebeldía y libertad en el ámbito social, político, literario y personal en los años de la transición a la democracia; liquidar una serie de moldes sociales, cultural y lingüísticos heredados para devolver la cultura al pueblo y hacerlo partícipe de nuevos aires frente al elitismo y la tendencia veneciana dominante; romper barreras lingüísticas y poéticas con el fin de transformarlas y de abrir espacios distintos de los convencionales y hacer "de la marginalidad y del enfrentamiento al dogmatismo una utopía habitable" ${ }^{34}$.

29 Ruiz Pérez, op. cit., p. 332.

30 María Rosal Nadales, "Antorcha de paja en el contexto de la transición", Cuadernos Hispanoamericanos, 784 (2015), pp. 113-121 (p. 114).

31 Rosal Nadales, op. cit.

32 Ruiz Pérez, op. cit.

33 Ruiz Pérez, ibidem, p. 336.

34 Juan José Lanz, Antorcha de Paja. Revista de poesia (1973-1983), Madrid, Devenir, 2012, p. 21. 
Su espíritu incendiario prendió en el panorama nacional con sus críticas a lo dado, la denuncia de la marginación andaluza, el inconformismo, el rechazo de la mayor parte de la poesía y de la cultura imperantes ${ }^{35}$ y su deseo de contribuir al remozamiento de aquel panorama poético y a la superación de las estéticas hegemónicas. Sus presupuestos ideológicos tenían una marcada inclinación hacia la novedad, un deseo de romper con las parcialidades y una doble intención de regeneración de la lírica del momento, acompasados por una aspiración al diálogo y al encuentro con otras poéticas. Sin orillar el propósito desmarcarse de la estética novísima ${ }^{36}$.

\section{De Antorcha de Paja a Degeneración del 70}

Desde que Manuel Altolaguirre y Emilio Prados publicaran Litoral (1926) en la imprenta Sur y, paralelamente, iniciaran una colección literaria del mismo nombre para dar cabida a los libros de sus correligionarios de generación, muchas otras revistas - la gaditana Alcaraván, responsable de con una colección del mismo nombre; Cuadernos de Ágora, con la editorial Ágora y, más cercana en el tiempo a Antorcha de paja, Trece de nieve con su colección Trece de nieve/Libros de poesía-, los editores cordobeses pretendieron afianzar sus fundamentos críticos con una propuesta cuyo primer germen fue Degeneración del 70. Antología de poetas heterodoxos andaluces.

Si bien en la parte inferior de la portada se reproducen el nombre de la editorial, su sede y la fecha de edición —Antorcha de Paja, Córdoba, 1978-, el depósito legal trae como ciudad y fecha de edición Granada, 1979; e informa como fecha de final de impresión el día 6 de diciembre de $1978^{37}$ —anecdóticamente día epifánico y simbólico, por ser el del referéndum que aprobó la Constitución española—, apareciendo como imprenta las granadinas Gráficas Solinieve, sitas en la calle Ricardo del Arco, 2.

Al igual que la revista, la colección estuvo dirigida por Gálvez, Álvarez Merlo y Amaro, nómina completada por Julio Juste en los trabajos de

35 Ruiz Pérez, op. cit., p. 327.

36 Lanz, op. cit., pp. 25-26.

37 A pesar de la fecha del depósito legal, para las citaciones se consignará el año de edición que aparece en la portada: 1978. 
diseño. Sin embargo, al contrario que aquella, el sello apenas perduró y tan solo publicaría otro par de volúmenes en 1981: Erosión de los espejos de Amaro ${ }^{38}$ y Un hermoso invierno de Gálvez ${ }^{39}$. Sin embargo, el espíritu de Antorcha de paja pervivió en proyectos como "Suplementos de Antorcha de paja”, entre 1984 y 1986, y, más tarde, "Trayectoria de navegantes".

La antología Degeneración del 70 salió de las prensas en un periodo de hibernación de la revista. Vino a ocupar el hueco dejado por aquella entre su segunda y tercera época (1977-1980) con la intención anexa de continuar con las reivindicaciones de libertad, subversión, innovación y revitalización del espacio creativo, según se refleja en la proclama con la que sus editores la califican. La publicitan como "una incursión, no modélica, sino libre, por territorios renovadores y vitales del espacio creativo". Como se argumenta en el prólogo que la encabeza, firmado por Manuel Abad,

Con el título de Degeneración del 70, la revista "Antorcha de paja" edita este libro que contiene parte del pensamiento y expresión poéticas de un grupo escritores andaluces sin que las identidades geográficas de cada uno de ellos hayan trascendido al poema en forma de desacertados y paradisíacos lugares comunes, como los de antaño; ni de purgatoriales tópicos, como los de hoy en uso ${ }^{40}$.

Degeneración del 70 acopió las voces de un grupo de doce poetas andaluces que, como Carlos Edmundo de Ory y otros disidentes, no entendían el mundo sin rebelarse. En sus bases doctrinales se hallaba la voluntad de acabar con lugares comunes sobre formas y motivos preexistentes e ir más allá de las trivialidades propias de las identidades literarias de entonces. Hacían bandera del alejamiento de la poesía andaluza de colorismo vacuo y modulaciones evasivas y, por el contrario, aspiraron a hacer de la novedad y de la vindicación de la heterodoxia sus rebeldes señas de identidad. Se trataba de una "degeneración asumida para agravar el código de lo establecido, de lo sublime”, según subrayaba Gálvez en la contraportada.

38 José Luis Amaro, Erosión de los espejos, Córdoba, Antorcha de paja, 1981

39 Francisco Gálvez, Un hermoso invierno, Córdoba, Antorcha de paja, 1981

40 AA.VV. Degeneración del 70. (Antología de poetas heterodoxos andaluces), prol. Manuel Abad, Córdoba, Antorcha de paja, 1978, pp. 7-8. En adelante, cuando se reproduzcan versos o se hable de poemas de la antología, la cita se encabezará con el título de la misma y la página correspondiente. 
Su espíritu iconoclasta los llevó, como el alacrán, a herirse y a herir la poesía, para, a partir de dolor y de la subversión, generar nuevas formas cuyo germen se nutrió de "la fe en la eficacia de las palabras y de las formas" ${ }^{41}$. Conforme a estos idearios, desde Antorcha de paja se apostó por unas formas léxicas familiares y ordinarias, alejadas, por tanto, de deslumbrantes ropajes culturalistas y recursos semánticos y/o simbólicos. Creyeron en la eficacia del lenguaje como factor de comunicación donde la poesía se erigiera en base para una eficaz interrelación entre el poeta y los lectores y donde las palabras discurrieran sobre la vida y las experiencias humanas con un lenguaje cotidiano y próximo al pueblo, modulado sobre expresiones íntimas y vitales no exentas de elementos narrativos. Se trataba de forjar una poesía fundamentada en la vida; una poesía cercana, humana y cordial, que hablase al corazón de los hombres; un punto de encuentro solidario donde el tiempo personal coincidiera con el colectivo y la vida particular se insertara en la historia colectiva de su tiempo ${ }^{42}$. No por ello sus protagonistas prescindieron de intertextualidades ligadas al cine y la literatura, de incursiones expresionistas o de conatos oníricos de ascendencia vanguardista. Vida y estética, ética y arte se aunaban frente a la deshumanización y la distancia del academicismo imperante y de las formas líricas de mayor impacto cultural. Hicieron de la vida un acto de existencia y de sus poemas incitaciones desde las que reproducir situaciones vitales concretas ${ }^{43}$, desviándose del refinado virtuosismo retórico o culturalista, la autosuficiente autonomía del arte, la apuesta decididamente antirrealista, la tendencia a la simbolización y la subjetividad o las formas neovanguardistas de los novísimos ${ }^{44}$.

Según orden de aparición, la nómina de la docena de poetas recogidos en la antología la integran: Fernando Merlo (Málaga, 1953-1981), María Luz Escuín (Granada, 1951), Justo Navarro (Granada, 1951), Juan de Loxa (pseudónimo de Juan García Pérez, Loja, 1944-Madrid, 2017), Rafael Álvarez Merlo (Málaga, 1945), Álvaro Salvador (Granada, 1950),

41 Abad, op. cit., p. 7.

42 Lanz, op. cit., 2012, pp. 57-58.

43 Abad, op. cit., p. 7.

44 Ángel Luis Prieto de Paula, Musa del 68. Claves de una generación poética, Madrid, Hiperión, 1996; Juan José Lanz, La llama en el laberinto. Poesía y poéticas en la generación del 68, Mérida, Editora Regional de Extremadura, 1994. Véase también José Infante, "1973-1983: Una antorcha encendida", Antorcha de paja, 17-18-19 (1983), pp. 10-11. 
Francisco Gálvez (Córdoba, 1945), José Luis Amaro (Córdoba, 1954), Manuel Lombardo (Jaén, 1944), José Infante (Málaga, 1946), Antonio Jiménez Millán (Granada, 1954 (1952) según la antología), y Joaquín Lobato (Vélez-Málaga, 1943-2005).

Salta a la vista que, a pesar de pretender una antología generacional, regional y subversiva, la nómina es tan heterogénea como heterodoxa y que el repertorio de poetas queda diluida "en su eficacia estética por unas premisas que se presentaban demasiado generales para definir una poética precisa y demasiado restrictivas para alcanzar la más alta calidad artística" ${ }^{45}$; a lo cual debe anudarse el que poco después las diversas propuestas se dispersarían en diferentes cauces desde el silenciamiento a la reorientación de sus discursos. Por ello resulta reduccionista en exceso la división en tres tendencias a cargo de Gómez Bedate: 1) la escritura de raíz onírica con una formulación discursiva que juega con procedimientos sintácticos al margen de la lógica representada por los cordobeses Gálvez, Amaro y Álvarez Merlo; 2) el caso de Justo Navarro caracterizado por una poesía basada en el collage lingüístico con apoyo de elementos textos de heterogénea procedencia; 3) un último grupo de poetas (Infante, Jiménez Millán y Merlo) que construye sus textos sobre la base de procedimientos narrativos para mostrar actitudes o situaciones rebeldes contra la sociedad burguesa ${ }^{46}$.

Desde el punto de vista generacional asoman datos significativos: la cercanía de sus fechas de nacimiento y, por tanto, el amparo de una coetaneidad y una formación dentro de circunstancias socio-culturales y políticas semejantes además de compartir el espacio geográfico andaluz como condicionante colectivo. Tan sólo once años separan la fecha de nacimiento de Joaquín Lobato (1943) —el sénior—, de la de Jiménez Millán y Amaro — los más jóvenes, nacidos ambos en 1954-.

Aunque la antología aspiraba a ser una propuesta conjunta andaluza desde la autonomía y la personalidad de cada autor, el proyecto se cifró en un triángulo geográfico formado por tres ejes de poetas: los editores cordobeses — Gálvez, Amaro y Álvarez Merlo-, los malagueños —-Merlo, Infante y Lobato-, y el grupo granadino —el más nutrido y representado en las figuras de Escuín, Navarro, Loxa, Salvador y Jiménez Millán-a los que se sumaría el jiennense Lombardo.

45 Ruiz Pérez, op. cit., p. 339.

46 Pilar Gómez Bedate, "Notas bibliográficas", Cal, 35 (septiembre, 1979), p. 24. 
De la docena de autores, siete ya habían publicado en Antorcha de paja. Además de sus rectores, la revista se había visto obsequiada con textos de Infante y Loxa, en su primera época, y de Navarro y Álvaro Salvador, en la segunda. Existían, por tanto, afinidades electivas y relaciones personales en pos de unas expectativas comunes que también eran alimentadas a través de otros cauces de colaboración en antologías y revistas como Poesía 70, Litoral y Letras del Sur, entre otras. Tan solo cuatro de los poetas antologados no aparecieron en ninguno de los cuadernos de Antorcha de Paja: Escuín —única representante femenina-, Lombardo, Jiménez Millán y Lobato.

Caso aparte es el de Fernando Merlo. No había colaborado con la revista, pero sus textos asomarán en su tercer periodo (no 15-16, marzo de 1982), al acoger la publicación cordobesa dos piezas del malogrado autor malagueńo como testimonio de reconocimiento y póstumo homenaje: "Oasis" y "A sus venas". Escritos en el otoño de 1981, poco antes de morir en octubre de ese año, ambos sonetos son considerados hoy paradigmas cimentadores de su leyenda de bardo yonqui, autodestructivo y contracultural. En ellos, la muerte se erige en motivo central de un poeta moribundo que percibía el desenlace de su ciclo vital, zaherido por la decrepitud de un cuerpo maltrecho, víctima de la adicción a la heroína, y también por los avatares de una carne sometida al abatimiento de "las rutinas y del opio". No le quedaba, pues, más salida que la serena y viril aceptación de una realidad implacable: "cumpla el ojo / sus ingratas labores" ${ }^{47}$.

\section{Fernando Merlo: poeta de la radicalidad y de la derrota}

En la hora de la impresión de este repertorio, los editores apuntaban que Fernando Merlo había publicado dos pequeños volúmenes: Al son de mi guitarra $^{48}$ y Cartas a Iska (El Guadalhorce, 1970). Sin embargo, los datos ofrecidos no responden a la realidad y dejan atrás pormenores no menos sustanciales. Editados en el taller del meticuloso impresor Ángel Caffarena, se distrae el título literal del segundo opúsculo —cuyo encabeza-

47 Luis García de Ángela, "El discurso roto", en El alambique. "Homenaje a Fernando Merlo”, 8 (nov 2013/abril 2014), p. 5. En https://www.fundacionalambique.org/index.php/publicaciones/revista/n8/homenaje-fm.html (consultado el 04/02/2020).

48 Fernando Merlo, Al son de mi guitarra, Málaga, Ángel Caffarena, 1970. 
miento correcto es Cartas a Elvira y a Iska ${ }^{49}$ - y se obvia que nació de una colaboración con el también malagueño Juan Ceyles Domínguez, ambos integrantes del Grupo 9. A ello se debe añadir que Merlo había sacado, en edición artesanal, un tercer volumen, Trepanación (1973) — con el artista cordobés José Ma . Báez- que, además de suponer un paso más dentro de una estética iconoclasta y vanguardista, ha sido calificado como testimonio elocuente de las difíciles relaciones que había proyectado sobre la poesía y su propia escritura: "un examen de conciencia ante el espejo congelado de la vida" para ver que no se gustaba al igual que le apesadumbraba un espacio público considerado como escenario que nublaba la razón ${ }^{50}$.

En los tres poemas recogidos en la antología sobrevuela la muerte como hilo conductor a través de tintes surrealistas no faltos de nihilismo y de amargura. Dos de ellos los protagoniza Nafa, sujeto lírico de la autoelegía fúnebre escrita por Merlo al comienzo de su trayectoria, que pasó a erigirse como eje de la segunda parte del libro Escatófago $(1983)^{51}$, rescatado tras su muerte por sus amigos. En ambos textos, representativos de su primera época, se aprecia la distancia entre el descaro inicial del personaje poético y su final. En el titulado "Nafa sonreía en los entierros", el personaje, de manera irreverente, se asomaba a la muerte para "Reírse de la apoteosis del miedo / Escoger la postura innoble" y "Echarse a reír como un tonto entre la niebla" (vv. 18-23) ${ }^{52}$. Sin embargo, frente a esta visión desenfadada, en "Elegía por la muerte de Nafa" se muestra el reverso de la existencia, la sórdida sombra de la muerte. "Como morimos todos", Nafa no pudo salvarse del naufragio porque no había un lugar para él en el mundo adulto. Sólo así, muriendo, se salvaba su inocencia, se preservaba su pureza, su ternura ${ }^{53}$.

49 Fernando Merlo, Cartas a Elvira y a Iska, Málaga, Ángel Caffarena, 1970.

50 Pablo García Baena, Los libros, los poetas, las celebraciones, el olvido, Madrid, Huerga y Fierro, 1995, p. 82.

51 Fernando Merlo, Escatófago, Málaga, Amigos de Fernando Merlo, 1983. El libro cuenta con dos ediciones posteriores a cargo de Federico Ortés (Madrid, Libertarias, 1992) y de Pedro Roso y Gloria Merlo (Málaga, Centro Cultural de la Generación del 27, 2004).

52 Degeneración del 70, p. 12.

53 Pedro Roso, "La verdad del adolescente atrapado. (Seis apuntes sobre la poesía de Fernando Merlo)", en El alambique. "Homenaje a Fernando Merlo", 8 (nov 2013/ abril 2014). En https://www.fundacionalambique.org/index.php/publicaciones/revista/n8/homenaje-fm.html (consultado el 04/02/2020). 
La muerte de Nafa revela la imposibilidad de luchar contra el devenir histórico y personal, la inevitable constatación de que la voluntad de vivir de una forma arriesgada, displicente o marginal no basta para superar las luchas intestinas ni para encarar una óptica social o ideológica al margen, radical y contracultural, en cuyo punto de fuga es donde "únicamente podía afianzarse un sujeto libre enfrentado a la opresión" ${ }^{4}$. La muerte acechante se convierte en realidad material: "Pero te has muerto, Nafa, y te has llevado / un trozo de esta tierra entre los dientes" (vv. 16-17) ) $^{55}$. Como apuntó Pedro Roso, "después de la muerte de Nafa, Fernando Merlo no acepta ningún freno, ninguna norma, ninguna restricción. Escribir es experimentar, buscar lo nuevo, indagar en lo oscuro, transgredir, extralimitarse. Un programa y una poética que cristaliza en "Trepanación»" 56 .

El último texto es ejemplo de su poética radical caracterizada por la sinceridad de una voz y un cuerpo dubitativo, derrotado: "—Qué inutili / dad de hombre! —acabo de acordarme / de que estoy muerto" $(\text { vv. 3-5 })^{57}$. Se da forma lírica a la voz de un poeta que percibía su existencia sitiada por los espectros del desgarro y de la escisión. Tuvo el valor de zambullirse en aguas profundas y oscuras para plasmar el envés del orden, la confusión y crisis de un joven poeta, la destrucción personal ejemplificada en la fractura del verso y de las bases lingüísticas.

Las tres piezas informan de la poesía de la radicalidad, de la derrota representativa de los convulsos cambios y las paradójicas circunstancias personales y colectivas que asolaron a su protagonista. Sus versos sombríos, visiones turbias y hostiles y descoyunturas formales no son sino demostraciones de las imágenes grises y del oscuro horizonte que nublaban voz y escritura. La praxis lírica no hacía sino corroborar las cuitas de un malogrado escritor inmerso en un viaje al interior de sí para mostrar su desamparo y debilidad en el contexto de la Transición.

Además de lo comentado sobre Merlo, respecto a la trascendencia en aquellos días de los autores seleccionados, cabe ser matizado que tanto la heterodoxia como la heterogeneidad son dos de las claves de bóveda de la antología.

\footnotetext{
54 Roso, op. cit.

55 Degeneración del 70, p. 12.

56 Roso, op. cit.

57 Degeneración del 70, p. 13.
} 


\section{Serios aprendices de poeta}

\subsection{Justo Navarro}

Justo Navarro no había editado ningún poemario. Sus versos sólo habían visto la luz en publicaciones periódicas como "Serie negra", que configura el monográfico no 9 de Antorcha de paja (agosto-septiembre de 1976). A aquel ciclo le darán continuidad los ocho recogidos en esta antología, cuya suma bien podría estar pensada como columna vertebral de un libro que nunca llegó a imprimirse.

El granadino pone en práctica unas formas líricas en las que se encabalgan motivos relacionados con la literatura y el cine negro — "Lolita", "Séptimo arte", "Ciencia Ficción" - aderezados con intertextualidades de todo tipo — Karl Max, Lenin, Friedrich Engels, Peter Cheyney, Karl Kaustky, Laurent Kornilov- y correlatos temáticos en los que se combina la reafirmación de la existencia — "Quiero vivir” — con una atmósfera de fondo alucinógeno y opiáceo — "otra vez las jeringas del deseo", "flota sobre la aguja carne fresca", "bajo el efecto de algún sedante" —, envuelta en tonos surrealistas: "la irrealidad de la realidad corre suelta" (v. 12) ${ }^{58}$. Los sentidos se confunden ante un marco histórico-social donde, a pesar de unas formas narrativas yuxtapuestas, huérfanas de signos de puntuación, y deliberadas disyunciones liberadoras de cualquier orden lógico, se alcanza a ver ecos de crítica y denuncia. Si en "Lolita" cuando enfoca la cámara "las botellas de suero / Cosecha del Setenta y Seis" emerge una pregunta retórica — “Qué opina usted de las huelgas de Enero?” (vv. 17$18)^{59}$ _, en "Séptimo arte", el objetivo entra por la ventana del garito y en la radio se escuchan noticias como "-Las movilizaciones de masas son delito" 60 .

La pericia y el intento de renovación estética de Navarro queda patente en la modulación de una práctica sinuosa donde se taracean estructuras que, subvirtiendo la organicidad del soneto, lo transgreden con el fin de hacer, de cada uno de sus ocho heterosilábicos textos, pequeños montajes fílmico-líricos. Sus estrofas, libres de los corsés estructurales del

\footnotetext{
58 Ibidem, p. 36.

59 Ibidem, p. 31.

60 Ibidem, p. 33.
} 
soneto italiano, toda vez que se inclinan a las libertades del isabelino ${ }^{61}$, se van superponiendo, alternando o secuenciando hasta configurar una narración fragmentaria en la que se suceden y confunden dos acciones paralelas: "la de un suceso privado de un oscuro personaje y la de un acontecimiento público del mundo de la historia más reciente" 62 . Los enmascaramientos narrativos, la experimentación con las personas verbales y la escritura automática con fondo de suspense oscurecen unos textos en cuyo desarrollo desdoblado se exhiben horizontes de derrota, turbios fotogramas de desolación y de muerte protagonizados por personajes escindidos que se saben víctimas; aunque no por ello puedan dejar de vagar entre crímenes, opresión, detectives, días sofocantes, espacios oscuros y escenarios nebulosos:

Otra vez las jeringas del deseo

De perder el sentido los bajeles

El mecanismo de la despedida:

Oscuro y vago como un recreo: [...]

Es la sangre la seña y el vaivén

Del transatlántico en un mar

Opaco y silencioso como mi vida:

Puesto a morir en las vías de un tren

Ya no esperes el Correo del Zar:

Laman los perros esta herida

De mal aspecto y de seguros daños:

Como viaje sin fin pasan los ańos: ${ }^{63}$

En cada una de estas secuencias fílmico-líricas, se perciben suficientes indicios para contrastar fondos sociales, problemáticas existenciales y conflictos morales colectivos propios de un marco social como el de la Transición, que cristalizan en unos poemas que, como el cine, ofrecen perspectivas de la realidad adulterada desde diferentes ángulos, planos en-

61 Cuatro textos se estructuran sobre la base estrófica de dos sextetos y un pareado: "Quiero vivir”, “Transporte pagado", "En la granja” y "Usted será intérprete”; los cuatro restantes sobre tres cuartetos rematados igualmente por un pareado.

62 Juan Manuel Molina Damiani, "Justo Navarro y el disfraz cifrado de su poesía. (Sobre las dos primeras muestras de su obra)", Zurgai (diciembre, 1995), pp. 4-6 (p. 5).

63 Degeneración del 70, p. 32. 
trelazados o secuencias que luego empleará con mayor acierto y extensión en su primer poemario: Los nadadores ${ }^{64}$.

\subsection{José Luis Amaro}

Dejando a un lado el volumen Versos con Penélope y marioneta de fondo (1973), repudiado por el autor, José Luis Amaro presentaba una trayectoria similar a la descrita respecto a Justo Navarro. Además de apariciones parciales en revistas, había dejado huellas de su lírica en varios números de Antorcha de Paja y, como aquel, será protagonista del número 10 de la revista (octubre-noviembre de 1976), constituyéndose ambos volúmenes en una suerte de homenaje a los dos poetas.

Los poemas de Amaro ofrecen una galería temática engarzada por unas tonalidades reflexivas reflejo de las preocupaciones del autor, piezas de raigambre metatextual y unos referentes articulados en modulaciones narrativas. Sus textos replantean dimensiones históricas y críticas a la vez que reafirman su compromiso con la realidad social. No en vano, el segundo poema ofrece como paratexto una cita de Passolini — "Fuera la tragedia, porque se ha de dar paso al pobre que sueña con la riqueza y el poder"65 para, linchados los cuerpos, faltos de esperanza por simulacros y apariencias sin trascendencia, desenmascaradas ya las farsas y despejados los anhelos de las barricadas de mayo, volver a reformular los principios de un tiempo capaz de encauzar nuevos rumbos y formular proyectos insurrectos: "hemos de volver a paladear / de la misma forma / el sabor de esa radicalidad / único contagio que la lucidez / establece consigo mismo" (vv. 37-41) ${ }^{66}$.

Las referencias de la epifanía creativa de Amaro son variadas. La fantasía de la realidad ficcionalizada, "traficante de sueños, / beoda semejanza con nuestras apariencias, / irrompibles como la nada que compone el ser" (vv. 29-31) ${ }^{67}$, es el cañamazo de "Poema Bogart", tributo al protagonista de El halcón maltés (John Huston, 1941), encarnación del héroe a contracorriente, cínico, vulnerable y sentimental de la edad de oro del

64 Justo Navarro, Los nadadores, Córdoba, Francisco Gálvez, 1985.

65 Ibidem, p. 80.

66 Ibidem, p. 81.

67 Ibidem, p. 83. 
noir. "Sobre menesteres del peregrino" fija su atención en la crudeza de los cuerpos deficientes, golpeados y desangelados de los peregrinos que, al final del día, codician un hospedaje y gozar del descanso del candor doméstico aunque, al contrario y además de lo que cabría esperar, al lado del reposo placentero y de la delectación hogareña se estimulan otros placeres - fantasías lascivas, envites amatorios - y se despiertan otros sueños — satíricos apetitos_ " "como estipendio amoroso, / del inocente cuerpo dormido / de la esposa o la hija del posadero" (vv. 22-24) ${ }^{68}$.

La filantrópica atención hacia el ser humano, la existencia y la acción, a pesar de las controversias inherentes, conforman el telón de fondo de "Cualquier negocio puede ser una locura", pieza en la que — desde la reiterada apelación a un "tú" receptor y amigo imaginario, desdoblamiento de nuestra intimidad ${ }^{69}$ — se apuesta por la comunicación entre poeta y lector. El "tú" es el motor de la acción de aquel, quien endereza el sentido de su vida y de su creación y el destinario de unas reflexiones que procuran desvelar verdades sobre el pasado, la amistad, la vida o el quijotismo como pulsión vital. Se reafirma el valor de la acción, a pesar de las dosis de locura aparejadas, aquí motor de transformación: "Pon tu grito en un puño, pon espada / a la garganta o serpentina de deseo / alocando cuerpos, porque esa calamidad / dulce de saberse vivos es contagiosa, / y cualquier negocio puede ser una locura" (vv. 23-27) ${ }^{70}$.

Los dos textos finales ejemplifican sendas líneas centrales de la primera época del vate cordobés: la dimensión amorosa y la reflexión metapoética. Mientras que en el penúltimo reflexiona sobre la naturaleza de la poesía y la condición de los poetas — profesionales de las trampas de la ficción, deambulantes fisgones en pos de las esquinas del pensamiento, barrenderos de dialécticas irredentas desde la soledad a la esperanza y, por fin, manipuladores de los asuntos más turbios, pero también seres dubitativos, zarandeados por la suerte o la sociedad, y comprometidos hasta la médula - en el texto final, con ascendente influencia algunos poemas de Tratado de urbanismo (1967) de Ángel González ${ }^{71}$, se (con)funden los

68 Ibidem, p. 79.

69 Ángel Estévez Molinero, La poesía de José Luis Amaro, Córdoba, Trayectoria de Navegantes, 1990, p. 39.

70 Degeneración del 70 , p. 82.

71 Ángel González, Tratado de urbanismo, Barcelona, El Bardo, 1967. 
piélagos del amor y de la poesía, de la pasión carnal y de lo metapoético. El amor, como la poesía, prefiere la desnudez de las formas, la apertura de pozos de deseo y música, los besos y las caricias, la soledad del instante, del encuentro deseado. En la vida, como en el amor y en la creación nada es desperdicio; al contrario, es motor del ser, placentero encuentro, siempre efectivo: "este dulce placer nos entusiasma, / cada inventario de amor, / cada armisticio entre sábanas" (vv. 15-17) ${ }^{72}$.

\section{Poetas EN CAMINO: EN BÚSQUEdA DE LA VOZ E IDENTIDAD CREATIVAS}

\subsection{Juan de Loxa}

De Juan de Loxa se obvia en Degeneración del 70 que había publicado Las aventuras de los... (1971) ${ }^{73}$ y se cita como inédito el libro Christian Dios en cada rincón de mi cuerpo (Libro de las monjas), escrito en 1974, aunque no vio la luz —incompleto- hasta $1982^{74}$. Los cuatro poemas recogidos: "Kodak", "Quería ser novicia aquel efebo motorizado", "Ceremonias litúrgicas (Flagelos)" y "Monja-Rock" pertenecen a tan singular volumen. En ellos se trufan referentes culturales con presupuestos religiosos constituyéndose como ejemplo del estilo jocoso y satírico de Loxa, dueño de una estética donde se combinan con similares dosis de gracia y frescura lo divino con lo terrenal, lo lúdico con lo impúdico, lo grave con lo burlesco, a través de efectos plásticos cargados de atrevida comicidad, ocurrente e irreverente, no muy del gusto de la alta literatura ni de los mandarines del canon.

El escritor granadino cultiva una poética postmoderna de ascendencia neovanguardista y entronques postistas. El oficio lírico es entendido como divertimento y aventura. Desde su perspectiva lúdica y desacralizadora, su obra se alza como práctica que busca a la par el humor desenfadado, la vis anticonvencional y el deseo de revolucionar mediante la provocación. Con voluntad de sorprender, alborozar y desacralizar por igual las estancias conventuales, el requiebro jocoso se combina con el impulso imaginativo

72 Degeneración del 70, p. 85.

73 Juan de Loxa, Las aventuras de los..., Jaén, Diego Sánchez del Corral, 1971.

74 Juan de Loxa, Christian Dios en cada rincón de mi cuerpo (Libro de las monjas), Granada, Silene Minor, 1982. 
y humorístico para fabricar textos donde la gravedad de los ceremoniales, la placidez de los hábitos, los recogimientos espirituales o las dimensiones de la vida consagrada se ven trasfigurados por protagonistas y actos que desvelan los lascivos ejercicios ocultos en las estancias conventuales. Las expectativas de la vida consagrada chocan contra una realidad caricaturesca y sarcástica, diametralmente antagónica. En una de las piezas un efebo aficionado a las motos aspiró a ser novicia y soñó con ofrecer fervorosos cánticos con los que allegar "flores a María cada mayo, salpicadas de grasa”, para acabar muriendo, ya anciano, "al borde de una misa del alba. [...]" mientras "las novicias-efebos, entre muslos, / lloraron azahares sobre el ara y las sábanas" (vv. 7-21) ${ }^{75}$. En otra, los anhelos de gloria celestial, los inciensos y maitines y las voces celestiales se truecan de forma grotesca para acabar con huesos y toca de "monja rockera" en "un cabaret de mala muerte / lleno de tetas y caderas" (vv. 12-13) ${ }^{76}$. Por último, en la tercera composición, se asiste a un ceremonial litúrgico situado en el contexto clásico de las albadas, durante el cual el martirologio de la flagelación no se ejecuta para purgar pecados u obumbrarse sino para gozar hasta acabar sucumbiendo por el éxtasis del nocturno placer parafílico ${ }^{77}$.

Mención aparte merece "Kodak", cuyo soporte referencial exhibe la realidad ficcionalizada de la fotografía no sin influjo de los mass-media. Engarza con la metáfora del mundo como teatro, como realidad impostada entre el plano real, el de la ficción lírica y el del resultado del objeto artístico, a los que se une el implícito deseo amatorio del protagonista. El encuadre fotográfico sirve como entorno para escenificar una inventiva erotizante entre fotógrafo y fotografiado a través de la visión del ojo físico y el de la lente, detrás del cual relumbra el objeto de deseo, todo ello entretejido por juegos experimentales con la forma, combinaciones tipográficas, ausencia de signos de puntuación, simbología audaz y una libertaria discursividad sintáctica.

75 Ibidem, p. 42.

76 Ibidem, p. 44.

77 Véase el poema "Ceremonias litúrgicas (Flagelos)": "La autopsia da la clave: / después de tanto amor / sobrevino la muerte. / Pues existió el abrazo, / la mecha interminable / de oración susurrada. / El verbo se hizo semen / y habitó en las heridas; / después de tanto amor / la languidez del lirio. / Mil desgarros de nuevo / al tic-tac de la luna / o aguja de gramófono. / Sobrevino la luz / y era la vida: / la que quedó en la colcha / después de tanto amor: / la espalda amoratada, / las teñidas ojeras, / mojado el calzoncillo. / Después de tanto amor, / en el museo un flagelo / colgando del perchero". Ibidem, p. 43. 
En definitiva, Juan de Loxa propone una poética iconoclasta, raíz cáustica y modulación burlesca y subversiva. Elude y trasgrede cualquier afán de trascendencia para hacer del discurso ficcional un espacio para la provocación, el humor desenfadado, el requiebro funambulesco y el ejercicio lúcido, con la premisa ulterior de mostrar el poema como una ingeniosa aventura ${ }^{78}$.

\subsection{María Luz Escuin}

María Luz Escuín es la única voz femenina representada en la antología. A la granadina, autora de un novel poemario titulado Extrasistole $(1975)^{79}$, publicado en la prestigiosa colección Zumaya, que ella misma había dirigido, se le brinda sustantiva importancia, dado que se le reservan muchas páginas del florilegio.

La impronta de Escuín no pasó desapercibida en el horizonte de la Transición aunque, con posterioridad, ha pautado en demasía sus entregas: Los versos en peligro $(1995)^{80}$ y Empleo terrenal $(2001)^{81}$, circunstancia que la fue exiliando del canon. Las causas se podrían inferir de su propia estética. Su corpus lírico cristaliza cuando siente absoluta necesidad de hacerlo; cuando se ha madurado con paciencia, fruto de una pulsión que se brinda poetizada como revelación de su sensibilidad y memoria esencial.

La selección ofrecida es representativa de un ideario de honda intensidad expresionista. No es fácil adentrarse en una poesía que mezcla la intuición alegórica y una figuración con tendencia a las imágenes en deconstrucción sintáctica. Las ideas se dispersan o se ciegan en una panoplia de posibilidades interpretativas, resultado de la creación de metáforas inusitadas $^{82}$. En palabras de Balcells, su original propuesta deriva tanto de su enrevesada e insólita perspectiva conceptual e imaginística como de su

78 Fernando Guzmán Simón, Léame antes de usar. Manual de instrucciones de los Juegos reunidos de Juan de Loxa, Granada, Editorial Alhulia, 2009.

79 María Luz Escuín, Extrasistole, Granada, Zumaya, 1975.

80 María Luz Escuín, Los versos en peligro, Madrid, Incipit, 1995.

81 María Luz Escuín, Empleo terrenal, Madrid, Devenir, 2001.

82 Francisco Morales Lomas, "Empleo terrenal”, Revista Intercultural Tres Orillas, (diciembre, 2005). 
adentramiento en la búsqueda de una lengua rara y propia, caracterizada por un "atrabiliario empleo del lenguaje" 33 .

Un primer acercamiento aboca al lector a la incertidumbre, al hermetismo y la desorientación de un lenguaje enrevesado y difícil de aprehender. Su proyecto parece escapar de las lógicas discursivas y de los dominios sintagmáticos en favor de nudos analógicos tan arcanos como audaces ${ }^{84}$. Sin embargo, todo comunica dentro de un tejido que emociona y desconcierta por mor de una sintaxis liberada de normas lógicas, una aparente arbitrariedad y unas yuxtaposiciones léxicas incongruas que derivan y apuntan al inconsciente y suscitan niveles referenciales y no referenciales. El lector queda así aprisionado entre ambas esferas hasta despejar el sentido del texto. De estos poemas emanan ejes enunciativos con valores éticos o formas de emocionalismo e intuiciones relacionados con la condición humana, inquietudes femeninas, problemáticas existenciales, miedos y trances individuales o representativos de los seres en su conjunto, pensamientos anecdóticos o territorios dispares a través de una mirada parcial, fragmentaria, gracias a la cual su escritura crea nuevos significados con los que comunica su visión del mundo.

La crudeza del parto, unida a la herencia matrilineal con los entrelazamientos y desasimientos materno-filiales y la separación momentánea o definitiva, abre unas piezas hilvanadas por un rosario de imágenes articuladas sobre un complejo entramado de analogías que ofrecen múltiples conexiones y sentidos 85 . A la sutil imaginería de las "Atractivas sugerencias para un suicidio" protagonizado por aquel "a quien las alegrías / hicieron incontables los espacios entre sus dedos" (vv. 8-9) ${ }^{86}$, y no le quedó

83 José María Balcells, Ilimitada Voz. Antología Poetas Españolas 1940-2002, Cádiz, Universidad de Cádiz, 2003, p. 49.

84 "Animales imprescindibles / cómo podríamos no gozar de esta mezcla. / Se acercan con sus vestidos elásticos / dirigiendo un patín sobre el hielo, / sueltos en la llanura / dando más de sí que una bailarina por los codos. / Estoy viva / y ellos que llevan un muro de inocencia en el lomo / me lo dicen. / Ellos que cierran el ciclo del calor / con avidez. / No busquéis leucemia más suave que sus labios / de ellos se aprende cómo acercarse / a la pelusa espesa de las plantas" (Degeneración del 70, p. 20).

85 Véanse como ejemplo versos del primer poema: "El hermano que falta / con la dependencia de la medusa / cuya única ventosa no ha cedido al mar. / Voy hacia ti con la diferencia mínima existente / entre un pecho y otro, / mis piernas se derraman hacia ti / mejor que un vaso de perfume" (vv. 11-17). Ver Degeneración del 70, p. 17. Ibidem, p. 19. 
más salida que la de precipitar su adiós, le siguen textos sobre el verano como estación adormidera. Protagonizan otras composiciones la juventud, con sus afecciones y trastornos, o la fragilidad del haz que separa vida y muerte, existencia y desaparición. Se amplían así las bases referenciales de una apuesta lírica que muestra la intensidad y diversidad expresiva de su creadora, así como la riqueza de motivos que sustentan una propuesta que viaja desde centelleos surrealistas o irracionales hacia la orilla de la conciencia. Los hilos argumentales crecen con indagaciones sobre el peso de la enfermedad, el arrepentimiento tras una relación fracasada, el descubrimiento de una lúbrica virilidad con ensimismada carga onanista, su sentido de pertenencia individualista y consecuente alejamiento paternal para finalizar con la exploración de las dimensiones sensoriales - tacto y olfato-, como cancelas de conocimiento y matrices para desentrañar otredades más allá de la propia sensibilidad.

En síntesis, Escuín plantea una poética que experimenta con un sistema lingüístico que aspira a ser trascendido mediante su alquimia figurativa. La anécdota cede protagonismo al conjunto, a la sugerencia, a las analogías audaces y a las transacciones metafóricas.

\subsection{Francisco Gálvez}

Francisco Gálvez había iniciado su andadura con Los Soldados (1973) ${ }^{87}$ en la editorial conquense El toro de Barro; una obra que continuaría con un segundo volumen inédito que pensaba titular Poemas racionales y al que, según consta en la presentación, pertenecían los siete poemas de la antología. Sin embargo, con dicho título no vería la luz ninguno de sus libros. Su segunda entrega, Un hermoso invierno ${ }^{88}$, apareció ocho años después, albergando algunos de los poemas reproducidos en Degeneración del 70.

A pesar de adherirse a los márgenes rebeldes y de su deseo contracultural, los siete textos de Gálvez ofrecen cierta ortodoxia, manifiesta tanto en sus formas - son poemas breves que oscilan entre los seis y los ocho versos- como en un lenguaje sintético y un punto críptico. No faltan rego-

87 Francisco Gálvez, Los soldados, Cuenta, El toro de barro, 1973.

88 Francisco Gálvez, Un hermoso invierno, Córdoba, Antorcha de paja, 1981. 
deos lingüísticos de ascendencia sincrética y minimalista, eliminación de lo superfluo en aras de una mayor depuración, sintaxis descoyuntada que altera la lógica discursiva - carente en muchos casos de puntuación-y unos fondos temáticos que persiguen la concisión y lo esencial con cierto flujo onírico. En "Invernadero", "Parque de las estatuas", "Objeto" y "Abdicación" ocupan un lugar relevante meditaciones esenciales sobre el paso del tiempo, la belleza y sus cualidades, el desenmascaramiento de la realidad y de sus enveses. Sus anécdotas se completan con las múltiples miradas que puede suscitar el objeto artístico y/o la abdicación de las viejas arquitecturas, el alejamiento de las estéticas previas, en aras de la voz personal, de la apuesta por lo propio y la audacia renovadora como contempla "Abdicación": "Por más que te pese la voz y el grito / si la audacia es propicia y los deseos claros / abdica de las viejas arquitecturas / porque nadie que no seas tú te dará la belleza / ni otro ejercicio te procurará / mejor imperio" 89 .

En su particular "Sátira" se armonizan — remozándose- tópicos clásicos como la vanitas vanitatis, entreverada con el tempus fugit, para conectar la efímera caducidad de la belleza con la finita orfandad del ser. El breve muestrario se completa con dos piezas en las que abogaba por una libertad sin preceptos, reforzándose el carácter solidario, audaz y comprometido, de un ideario en el que se aúnan camaradería, ideología, libertad y rebeldía condimentadas con cierta anarquía consustancial a la juventud: "Porque tu libertad que es la mía / no comprometida por fuero o razones / sentencia o dictamen sin adorno ni compostura / es audaz en secreta adolescencia. / Pues así como a la belleza innecesarios / le son los incentivos, un corazón joven / ideología no necesita" ${ }^{\text {90 }}$.

\subsection{Antonio Jiménez Millán}

Según los editores, Antonio Jiménez Millán se presentaba como autor con una obra publicada antes de Degeneración del 70 . Sin embargo, además de Último recurso $(1977)^{91}$, premio García Lorca en 1976, como se indica en

89 Degeneración del 70, p. 71.

90 Ibidem, p. 75.

91 Antonio Jiménez Millán, Último recurso, Granada, Universidad de Granada, 1977. 
el frontispicio que abre su sección, se desatiende que el granadino se había significado con Predestinados para sabios $(1976)^{92}$.

Los cinco poemas ofrecidos por Jiménez Millán son representativos de sus primeros años. Hacen gala de una linealidad referencial que lo conducirá hacia formas vinculadas con la poesía de la experiencia. La voz poética deambula entre las imprecisas fronteras que unen y separan lo privado de lo público. En sus versos se agolpan y se (con)funden sentimientos, deseos y conciencia de la realidad con cierta cadencia elegíaca y el sustrato del motivo de la soledad como único y definitivo argumento existencial.

Desprendido de toda hojarasca retórica o culturalista, el poeta acuña los embriones de un nuevo lenguaje abordado desde la intimidad de un discurso eminentemente ideológico. Se aprecia la irrupción de un sujeto poético que busca una dicción capaz de dar cuerpo a situaciones privadas — familiares, amorosas, sociales - para ahondar luego en su condición contradictoria, adecuándose al tejido de emociones que busca reproducir ${ }^{93}$.

Los cinco textos entreverados de narratividad y estampas realistas ofrecen un muestrario de la vida de un sujeto sentimental con sus dolores y sobresaltos, acuciado por los recuerdos y una conciencia del tiempo y de la memoria con "muertos bajo la niebla o el último vaho de los suburbios" (vv. 9-10) ${ }^{94}$; manifiestos claroscuros de unos horizontes temporales sombríos donde los desengaños crecían como la yedra. Se escenifican evocaciones del desencanto, de un tiempo pasado y dramático y de una realidad degradada, marcada por el hastío y la soledad. Los personajes recorrieron el tiempo de la luz y los escombros, del miedo y de la desesperanza ante el que solo quedaba rebelarse: "No hay mejor aprendizaje que la calle y un tiempo y una vida a cambiar" (vv. 20) ${ }^{95}$.

Jiménez Millán reconstruye una conciencia temporal y una escisión de la vida y de la memoria en la cual se alza la derrota como equipaje en ciudades frías, calles crepusculares, restos de alcohol y madrugadas hirientes.

92 Antonio Jiménez Millán, Predestinados para sabios, Málaga, Ángel Caffarena, 1976.

93 Andrés Soria Olmedo, "Una mirada atenta”, Ínsula, 498 (1988), p. 29. Véase también Francisco Díaz de Castro, "La poesía de Antonio Jiménez Millán", en Poesía española contemporánea. Catorce ensayos críticos, Málaga, Universidad de Málaga, 1997, pp. 273-305 (pp. 278-279).

94 Degeneración del 70, p. 111.

95 Ibidem, p. 112. 
Los resentimientos y las amarguras serpentean para oscurecer los jirones de una vida que se desliza, incognoscible, para agudizar la desolación del protagonista. En la propuesta de Jiménez Millán se escenifica la distancia entre las cargas de la atosigada vida profesional y el derrumbamiento del individuo. La conciencia poética envuelta en los cortinajes de la soledad desliza la imagen rota del sujeto que, derrotado, vuelve a su hogar para sufrir los estragos del hombre gris. Nadie conoce la otra realidad, la del insomnio perturbador, la de la sombra privada de la habitación, la de la fiebre, las manchas de sangre y el sentirse como un espantapájaros inmóvil y desheredado. Su zozobra pertenece al reino de lo privado, a las sombras ignoradas de la noche y del hogar: "De noche sube / la fiebre llegas al vómito / ya no cuentan los datos / solo un cuerpo que se revuelve entre las sábanas / solo la neurosis y su correspondiente / VIDA PRIVADA" (vv. 19-24) ${ }^{96}$.

\section{Poetas con EQuipaje}

\subsection{Rafael Álvarez Merlo}

Antes de Degeneración del 70, Rafael Álvarez Merlo había publicado un par de poemarios: Revival (1971) ${ }^{97}$ y Elegía contemporánea (1976) ${ }^{98}$. Los diez poemas compilados, algunos ya conocidos, ofrecen un divergente muestrario que oscila desde un sincrético soneto de cuńo biografista —el poeta se presenta como ser "estrafalario, / de infancia gris y educación marista, / cerebro problemático, anarquista» y de "re corazón volucionario" (vv. 1-4) ${ }^{99}$ — con aparejada defensa de la fraternidad, el humanismo filantrópico y el compromiso social como patrias del ser humano y del poeta, hasta la demanda de abolición de los "Usos y costumbres" en favor de locuras íntimas, renovadoras mañanas y una inveterada juventud cuyo cuerpo aún se prevé que tarde "generaciones en crecer" (vv. 10) ${ }^{100}$.

96 Ibidem, p. 114.

97 Rafael Álvarez Merlo, Revival, Málaga, Ángel Caffarena, 1971.

98 Rafael Álvarez Merlo, Elegía contemporánea, Córdoba, Escudero, 1976.

99 Degeneración del 70, p. 47.

$100 \mathrm{Ibidem}$, p. 56. 
Huérfanos en ocasiones de signos de puntuación, entreverados de hallazgos neovanguardistas y dechados de una dimensión figurativa que no se priva de alterar los ritmos sintagmáticos, en los poemas de Álvarez Merlo no escasean los guiños metapoéticos, las denuncias del lenguaje y paraestrofas postuladoras de la afirmación de la existencia, de la libertad ("no al brazo tirano y prostituto" (vv. 9)), del amor y de la vida ("me niego I y testifico amar la vida extraordinariamente" (vv. 16-17) ${ }^{101}$ aun a sabiendas del voraz paso del tiempo. Para completar sus fundamentos, con una dicción irónica y gran libertad formal, se despliegan la crudeza de la vida, la tristeza y el sufrimiento apreciable en unos ojos doloridos, bellos "a la hora de la muerte" (vv.17) ${ }^{102}$. No faltan tampoco soplos surrealistas y jocosos, con el telón de fondo de un amor de imaginería religiosa donde el lienzo simbólico acaba en éxtasis voraz: “apáguese el recato / tiempo no es de escapar / porque ya no tenemos tarde amor mío amor / por si no lo entiendes / qué tibios siento los cojones" (vv. 17-20) ${ }^{103}$.

\subsection{Manuel Lombardo y Joaquín Lobato}

Con tres volúmenes contaban las trayectorias de Manuel Lombardo y Joaquín Lobato antes de antologarse en Degeneración del 70. Lombardo había publicado Ahora Blancanieves cojea algunas veces de mi mano $(1974)^{104}, E l$ Tigre y la Mariposa (1976) ${ }^{105}$ y De jaulas, espejos y relojes (1978) ${ }^{106}$. Desde una concepción que entiende la poesía como "un placer en sí mismo y una lucha por lo imposible"107, el jiennense se califica como atípico y heterodoxo alejado de círculos institucionales o tentativas uniformadoras.

Su credo estético aboga por axiomas de sencillez formal y hechuras de ánimo meditativo. Conjuga breves percepciones vivaces con unos temas

101 Ibidem, p. 52.

102 Ibidem, p. 51.

103 Ibidem, p. 48.

104 Manuel Lombardo, Ahora Blancanieves cojea algunas veces de mi mano, Jaén, Unión Tipográfica, 1974.

105 Manuel Lombardo, El Tigre y la Mariposa, La Carolina, La Peñuela, 1976.

106 Manuel Lombardo, De jaulas, espejos y relojes, Jaén, Cuadernos de Aixas, 1978.

107 Ginés Donaire, "Manuel Lombardo hace "una indagación implacable del hombre de hoy" en su poesía”, El País, 16 Junio, 2004. 
explícitos, objetivables, que oscilan entre las divergentes encrucijadas del amor, la lírica como provocación y las reflexiones metapoéticas de carácter lúdico ${ }^{108}$. En su obra se equilibra una concepción desmitificadora, en ocasiones festiva, del proceso creador con motivos que invitan a la reflexión; apuesta, en suma, por una linealidad que recuerda a Gloria Fuertes ${ }^{109}$ y a lo que Umberto Eco denominó double coding, técnica combinatoria que se presta y a una lectura sencilla y superficial y a otra más profunda y reflexiva ${ }^{110}$.

Sus versos no vacilan en ser críticos y rebelarse contra sí mismo y contra el pasado. Por otro lado, los afectos y los tonos vitalistas y sentimentales alternan con motivos positivo-existencialistas y con un deseo de gozar de lo cercano, hasta lo más insustancial, a través de un lenguaje que aborda asuntos cotidianos ${ }^{111}$. Lobato concibe la poesía como algo próximo; nos habla de la alegría de sentirse vivo y de gozar de la ternura como eslabones de un tiempo nuevo que se abría camino entre los miedos del pasado inmediato.

El jiennense persigue el placer artístico de la lectura y de la poesía como fuentes de verdad, de reflexión y de vida; pero también de dicotomías, de lucha contra lo imposible, contra la palabra y el lenguaje, de ficción y de deleite que despierte sonrisas al lado de meditaciones. No se obvian los azotes a los poderes fácticos y las consecuencias del naufragio de una historia demasiado cercana que debía ser superada a través del compromiso común: "Largo tiempo hemos sido triturados: / Levántate y acude, cuerpo mío, / a la fiesta de la vida rebosante, / al clamor de la vida libertaria y / compartida" (vv. 12-16) ${ }^{112}$; aunque para ello sea preciso alzarse, hacer de la rebelión una ética y un proyecto de vida no exento de humor y bifrontismo: “[...] fotografíese en la cámara personal / e irrepetible de sus días. / Si el revelado da óvido, / reptil, espantapájaros o cualquier / otra figura

108 "Dos moscas / se hacen el amor / en la cortina. / Y yo que intento / hacerle el amor / a la cuartilla, / va la muy infame / y se me niega". Degeneración del 70, p. 90.

109 Gloria Fuertes, Obras incompletas, Madrid, Cátedra, 1981.

110 Umberto Eco, Confesiones de un joven novelista, Barcelona, Lumen, 2011.

111 "Aquí tenéis mis sencillas alegrías: / Sentirme vivo y respirar el aire, / tomar el sol, / mojarme con el agua, / detrás de un rostro, adivinar un nombre, / quedarme sin edad jugando con los niños". Degeneración del 70, p. 97.

112 Degeneración del 70, p. 99. 
deprimente, / intente cambiar fisonomía, [...] sepa usted [...] que no hay otra forma de vivir/ que REBELÁNDOSE” (vv. 2-11) ${ }^{113}$.

Según la antología, y de modo semejante al caso de Lombardo, el malagueño Joaquín Lobato había escrito tres poemarios en años linderos a los de la antología cordobesa: Dedicadas formas y contemplaciones $(1975)^{114}$, La careta $(1976)^{115}$ y Farándula y epigrama $(1976)^{116}$. Conviene advertir que media lo suyo entre la enunciación de sus primeras entregas —iniciáticas, existenciales y preñadas de sentimentalismo- respecto a aquellas donde el autor conquistó una dicción propia, reconocible y disidente.

La disposición de estos textos, que más tarde engrosaron la tercera sección ("Estuche y alcanfor") de Infártico (Granada, 1982)117 —excepto "Testamento", que se incorpora a la segunda, la misma que da título al libro-, supone ya una dialéctica discrepante respecto a los cauces ortodoxos. Dejando a un lado "Desvaídos los recuerdos", juega con una distribución experimental de las formas y de cada palabra mediante arbitrarios cortes estróficos, alternando versos con un solo vocablo - ya sean artículos, preposiciones o sustantivos - con otros en los que dos, tres, cuatro o cinco palabras discurren más o menos arbitrariamente.

En su ideario se percibe que el "lenguaje no está compuesto sólo de oraciones sino que cada uno de sus componentes desagregados tiene —además - su propio fragmento de significación y — sobre todo- de sugerencia"118; es decir, la descomposición de los enunciados es recompuesta en el subconsciente gracias a imágenes subyacentes. Al lado de la fragmentación y de la búsqueda de la palabra exacta, ceñida a la sugerencia inefable que despiertan los significantes, su obra se completa con palimpsestos cultos y populares: desde el Arcipreste de Hita o Quevedo a Popeye, Edith Piaf, Machín y Charlot pasando por Marcelino Pan y

113 Ibidem, p. 100.

114 Joaquín Lobato, Delicadas formas y contemplaciones, Málaga, El Guadalhorce, 1975. 115 Joaquín Lobato, La careta, Málaga, Ciudad del Paraíso, 1976.

116 Joaquín Lobato, Farándula y epigrama, Málaga, El Guadalhorce, 1976.

117 Joaquín Lobato, Infártico, Granada, Diputación de Granada, 1982.

118 Enrique Zattara Hernández, "Reconstruir la gramática del sentimiento, para recrear poéticamente una Andalucía atópica (estudio sobre la obra de Joaquín Lobato)”, Boletin de la Sociedad de Amigos de la Cultura de Vélez-Málaga, 11 (2012), pp. 69-78 (p. 72). 
Vino, el Cid, Stan Laurel y Oliver Hardy o Juan sin Miedo, entre otros; vestigios de los mitologemas de su educación sentimental.

Lobato concibe una poética que hace uso del recuerdo y de la interrogación sobre el pasado como territorios por los que transitar hasta un presente —el momento de la escritura - en el que, con nostalgia, se evocan para recuperarlos. Se hacen visibles aquellos primitivos universos y los posos sentimentales que, como en "Testamento", a guisa de última voluntad, nos son legados literariamente: "un retrato / del / Arcipreste de Hita. / Un / recuerdo / envuelto / en / papel de chocolatina /, dos versos copiados / de / Quevedo / el / ojo / roto / de / un / muñeco / viejo / y / los músculos de Popeye" (vv. 5-24) ${ }^{119}$. A su lado, encontramos textos con mayor carga crítica y social, denunciadores de hechos cargados de dramatismo, verbigracia en "mamá Elvira (vecina mía)", donde una mujer sufre con el recuerdo del hijo asesinado en la guerra.

\section{BAGAJE DE POETAS CON ALFORJAS. JOSÉ INFANTE Y ÁlVARO SALVADOR}

José Infante y Álvaro Salvador eran los dos creadores con mayor trayectoria de cuantos se aglutinaron en Degeneración del 70.

Con varios poemarios a sus espaldas, Imágenes sucesivas (1970) ${ }^{120}$, Uranio 2000. Poemas del caos (1971) ${ }^{121}$, La uva duodécima (1976) ${ }^{122}$ y La nieve de su mano (1978) ${ }^{123}$ y un premio de la categoría del Adonais por Elegía y no (1972) ${ }^{124}$, de José Infante se reproducen cinco textos. Algunos de ellos giran en torno al amor en sus múltiples vertientes. "Del recuerdo del amor" alza un lamento ante el recuerdo de un amor deseado y deseante que no regresa. En "Homenaje a San Juan de Cruz" se rememora un amor homoerótico inspirado en la lírica de San Juan de la Cruz. El sujeto lírico relata sus amores con un amigo drogadicto llamado Juan quien

119 Degeneración del 70, p. 119.

120 José Infante, Imágenes sucesivas, Málaga, El Guadalhorce, 1970,

121 José Infante, Uranio 2000.Poemas del Caos, Málaga, El Guadalhorce, 1971.

122 José Infante, La uva duodécima, Málaga, El Guadalhorce, 1976.

123 José Infante, La nieve de su mano, Madrid, Pentesilea, 1978.

124 José Infante, Elegía y No, Madrid, Adonais, 1972. 
"de noche / subía hasta mi habitación / por la secreta escala" (vv. 3-6) (25 $^{12}$ regalándole episodios de amor con el velo nocturno como aliado hasta que, víctima de la desolada navegación que le depara la vida a quienes son seducidos por la mano estigia de la droga, "un día, en su viaje, / mi amigo Juan buscó más alto vuelo / y le perdí el amor y el desespero" (vv. $16-18)^{126}$.

En "Plaza Mayor" se aúna lo descriptivo con una humanización del espacio. La soledad, la desilusión y la desesperanza se dan la mano aquí con la falta de estímulos y el nihilismo: “¿por qué la luz no habla? ¿es justa la esperanza? / ¿dónde se esconde la fuerza del que muere?” (vv. 12-13)127. Apenas sobrevive un árido deseo de búsqueda y un presentimiento de desolación ante un conjunto de factores de distinto orden que convergen en la sensación de soledad, quietud y vacío existencial. Finalmente, en "Ángeles huyen a Venecia”, homenaje a Ginés Liébana recogido después en El artificio de la eternidad (1985) ${ }^{128}$, se alzan dos motivos: los ángeles - expresados y recreados por uno de los pinceles del grupo Cántico-y Venecia, cuna y símbolo de la poesía de los novísimos. De ahí que también el texto se estructure en dos partes: una de carácter historicista, que relata mediante enumeraciones el paso de los ángeles desde lo legendario y religioso hasta su metamorfosis en héroes eternamente jóvenes; y la segunda, protagonizada por Venecia, anclaje para esos efebos de la luz y del misterio, dueños de prohibidos frutos.

La poesía de Álvaro Salvador fue reconocida de inmediato al alzarse con premios universitarios como el García Lorca (1971) por Y... ${ }^{129}$, el Nacional Universitario (1972) por La mala crianza (1974) ${ }^{130}$ y el Certamen Internacional "El Olivo" por Los cantos de Ilíberis (1976) ${ }^{131}$. Estos volúmenes junto con De la palabra y otras alucinaciones $(1975)^{132}$ participan de directrices de ascendencia novísima a las que se unen testimonios

125 Degeneración del 70, p. 103.

126 Ibidem, p. 103.

127 Ibidem, p. 104.

128 José Infante, El artificio de la eternidad, Málaga, Puerta del mar, 1985.

129 Álvaro Salvador, Y..., Granada, Universidad, 1971.

130 Álvaro Salvador, La mala crianza, Málaga Ángel Caffarena, 1974.

131 Álvaro Salvador, Los cantos de Ilíberis, Jaén, El olivo, 1976.

132 Álvaro Salvador, De la palabra y otras alucinaciones, Vélez-Málaga, Arte y Cultura, 1975. 
más personales, como los de las reflexiones sobre el discurso poético que alcanza su madurez en Las cortezas del fruto (1980) ${ }^{133}$. Este libro incorpora los textos aquí glosados, algunos ya reproducidos en revistas como Papeles de Son Armadans o Antorcha de paja. El granadino materializó entonces su "profesionalización poética" delineando

un mapa de antinomias entre un estado de la poesía (la inmediatamente anterior promoción "novísima") [...] y un proyecto, vertebrado [...] como pronunciamiento teórico y como práctica de escritura: ideología y praxis que [...] seguirán dando sus "frutos" en poemarios posteriores $^{134}$.

Su referente no es otro sino la conciencia material y espiritual de la palabra poética y su funcionamiento. Sus versos tratan de descortezar el fruto hasta llegar a la semilla. Su doctrina se fundamenta en la reflexión y práctica de las bases autorreferenciales y los replanteamientos sobre todo lo que gravita "La práctica poética teórica" o "Rancio lugar común", precisos pero sustanciales poemas, cifra del impacto en su obra del pensamiento del maestro Juan Carlos Rodríguez en aspectos como el poeta, su ámbito de actuación - la poesía - y sus materiales e instrumentalización: la conciencia de falsificación, el compromiso activo, la distancia entre la experiencia real y su traslado ficcional, la voluntad del autor y sus intenciones y su utilidad como parte de una lucha ideológica dentro de la historia individual y colectiva.

Al lado del pensamiento teórico-doctrinal y del cuestionamiento del ámbito artístico, pasado y presente, en estas piezas se despejan los mecanismos de construcción de sus textos. En un "Rancio lugar común” se publica la intención última de desvelar que el poema es ficción, un artificio de prestidigitador. Su propuesta es indagatoria y reflexiva. "Cherchez la femme" opera sobre una base metapoética en la que se busca el cuerpo material que construye "el espacio blanco", "No penséis en la ausencia / en el espacio blanco [...] Pensad que en vuestro lecho / desprovisto de nombres y sonidos / ha de haber siempre una mujer desnuda" (vv.

133 Araceli Iravedra, Poesía de la experiencia, Madrid, Visor, 2007, p. 179.

134 Marcela Romano, "Álvaro Salvador o la ofensa a la poesía", Texturas, 7-7 (2007), pp. 147-161 (p. 149). 
1-14) ${ }^{135}$. Dicha búsqueda permanece en estado latente hasta que se materializa "la fuerza oculta / de un discurso vacío, / ausente de palabras y de historia” (vv. 16-18) ${ }^{136}$.

Los poemas se construyen sobre sí mismos, sobre sus artilugios internos y el desvelamiento de sus tramas e ideología. Se visibilizan los juegos de espejos y las máscaras que los envuelven, los códigos que los ordenan y reglamentan históricamente para hacernos ver que las palabras no dicen nada en sí mismas "con qué suerte de inútiles y mágicas palabras / supuestamente mágicas, en realidad trucadas, / confías en construir una belleza / una falsa belleza que a nada te conduce [...]" (vv. 7-9) ${ }^{137}$. Los significantes no alcanzan su significado hasta que el cuerpo sintagmático no se integra y da sentido a su entidad material al final del poema donde se desnuda su ficción, su inventiva, las leyes internas de ese "Rancio lugar común” sobre que se edifica "La Gaya ciencia": "con que torpe mentira: premeditado engaño / has llegado hasta aquí / construyendo un poema" (vv. 12-14) ${ }^{138}$.

9. Degenerados y Heterodoxos De AYer QUe Abrieron CAUCES PARA HOY

Manuel Abad caracterizó Degeneración del 70 como una suma de existires, una forma de conciencia colectiva tras la cual vociferaban, a veces con desesperación, otras con rebeldía y muchas con patetismo las existencias individuales ${ }^{139}$. La antología pareció concebirse como una amalgama de perfiles cuyo fondo común venía a ser su heterodoxia respecto a los cánones de los grupos de Madrid y Barcelona.

Desde diferentes parámetros, se postulaba una ruptura frente a la literatura oficial y la defensa de otros discursos. Sin embargo, a pesar de la individualidad de cada cual, no se puede orillar que el agrupamiento los heterodoxos andaluces venía a tender puentes entre Antorcha de Paja

135 Degeneración del 70, p. 64.

136 Ibidem, p. 64.

137 Ibidem, p. 65.

138 Ibidem, p. 65.

139 Abad, op. cit., p. 7. 
y buena parte del Colectivo 77, al calor del magisterio de Juan Carlos Rodríguez, resuelto a superar la dicotomía entre razón y sentimiento consagrada por la estética burguesa.

Sus protagonistas comenzaron a concebir la poesía como un acto de existencia y autoafirmación que aspiraba a fundir vida y poesía y a recrear en el poema situaciones vitales concretas: "la muerte del amigo, el desengaño amoroso, la asistencia al cinematógrafo donde se proyecta un filme de cine negro, la noticia de un famoso asesinado o bien el asombro ante una potente eyaculación de adolescencia" ${ }^{140}$. A su lado, se dejan ver incipientes correlatos temáticos que pronto devinieron en lugares comunes para determinados colectivos: pensemos en los aires metapoéticos. Se multiplicaron a su vez los poemas narrativos con visos biográficos, textos protagonizados por un personaje autoficcionado y propuestas comenzaron a considerar la poesía como arma contracultural, lúdica y lúcida que faculta para experimentar con el lenguaje, sin descuidar los temas realistas y sociales: la maternidad, la droga, el suicidio o la homosexualidad.

Fueron poetas degenerados del 70, herederos de las proclamas de mayo del 68 en su afán por abrir brechas en el sistema y hacer bandera de la crítica y de la subversión sintáctica e incluso estrófica donde no faltaron dosis de humor e ingenio. Los poetas de esta antología cordobesa experimentaron con el lenguaje como instrumento de creación y conocimiento. Ampliaron los márgenes de la lógica discursiva mediante el ensanchamiento referencial y figurativo y la incorporación de nuevos temas envueltos por un rebelde humanismo con causa.

140 Ibidem, p. 7. 